\title{
Reviewing the Silent Enemy of Faculty Mobbing
}

\author{
Rugayah Hashim¹, Zaidi Mohd Aminuddin², Ayu Rohaidah Ghazali², Norfadzilah Abd Razak² \\ ${ }^{1}$ Research \& Innovation Division, 2 Faculty of Business \& Management, \\ Universiti Teknologi MARA Cawangan Selangor, Puncak Alam, Selangor, Malaysia
}

guy73106@yahoo.com, pmzaid@yyahoo.com.my, ayurohaidah@gmail.com, norfadzilah0438@gmail.com Tel: +6013-3852288

\begin{abstract}
The objectives of this review article are to highlight the prevalence of faculty mobbing through literature search and analyses. In an academic environment where most of the populace is involved in tertiary education, it is expected that mobbing or bullying would occur in the uncivilized surrounding. However, the opposite is true; faculty mobbing is a silent enemy in an academic setting, and there is a need to improve the situation to preserve the auspices of a university. The findings indicated that mobbing is endemic at universities and will threaten the university's reputation. Therefore, it is recommended that the university's executive management be more concerned with the prevalence of faculty mobbing will affect workplace happiness.
\end{abstract}

Keywords: Mobbing; Bullying; Faculty; Workplace Happiness

eISSN: 2398-4287 @ 2019. The Authors. Published for AMER ABRA cE-Bs by e-International Publishing House, Ltd., UK. This is an open access article under the CC BYNC-ND license (http://creativecommons.org/licenses/by-nc-nd/4.0/). Peer-review under responsibility of AMER (Association of Malaysian Environment-Behaviour Researchers), ABRA (Association of Behavioural Researchers on Asians) and cE-Bs (Centre for Environment-Behaviour Studies), Faculty of Architecture, Planning \& Surveying, Universiti Teknologi MARA, Malaysia.

DOI: https://doi.org/10.21834/e-bpj.v4i12.1770

\subsection{Introduction}

Workplace happiness depends on collegiality and interpersonal relationship between and among employees. In an academic environment, the thought that mobbing or bullying exists within an ivory tower is unheard of. However, the issue does exist, as evidenced by literature. Faculty bullying and mobbing become prolonged when there is no action taken by the university management, thus making it difficult to resolve. Again, as shown from literature, there are higher incidences of mobbing happening in academia than in any other work setting (Hollis, 2015). Nonetheless, occurrences of faculty mobbing have been brought to light through whistleblowing and complaints from the victims, but the issue remains a silent enemy. Therefore, the objectives of this review article are to highlight the prevalence of faculty bullying and mobbing through literature search and analyses.

\subsection{Literature Review}

\subsection{Defining Bullying versus Mobbing}

Bullying can occur anywhere. Bullying is much like harassing, offending, socially ostracizing another colleague that negatively affects the colleagues' work ambiance (J. E. Lester, 2013; Thirlwall, 2015). One person in a prominent position usually does the bullying, as evidenced by literature. Mobbing, on the other hand, is more common in universities (Keashly \& Neuman, 2010; J. Lester, 2013). Mobbing is a form of social elimination after singling out one academician who is perceived to be problematic (Prevost \& Hunt, 2018). Mobbing differs from bullying because other academicians are ganging up against the targeted individual (Keim \& McDermott, 2010).

eISSN: 2398-4287 @ 2019. The Authors. Published for AMER ABRA cE-Bs by e-International Publishing House, Ltd., UK. This is an open access article under the CC BYNC-ND license (http://creativecommons.org/licenses/by-nc-nd/4.0). Peer-review under responsibility of AMER (Association of Malaysian Environment-Behaviour Researchers), ABRA (Association of Behavioural Researchers on Asians) and cE-Bs (Centre for Environment-Behaviour Studies), Faculty of Architecture, Planning \& Surveying, Universiti Teknologi MARA, Malaysia. DOI: https://doi.org/10.21834/e-bpj.v4i12.1770 
The ultimate intention is to drive the victim out of the school or university. Mobbing is also found to be on a larger scale because of the number of individuals roped into the situation (Duffy \& Sperry, 2012).

\subsection{The student bullying the professor}

As evidenced by the literature, bullying works both ways. It is thought that bullying only occurs between a person in power over a subordinate victim, such as a professor and a student or supervisee. The other way around is possible; that is, the student bullies the professor or supervisor (May \& Tenzek, 2018). Such an act is termed contra power harassment invoked by student incivility (Lampman, Phelps, Bancroft, \& Beneke, 2009). To reiterate May \& Tenzek (2018), the bullying of professors indicated a shift in the typical power dynamic associated with bullying. Although the professor does have the upper hand in controlling and containing the situation, the possibility of the student getting his or her way is definite. For example, if a post-graduate student confronts a professor with accusations of limited face-to-face supervision, then there is a need for the school to investigate the legitimacy of the charge. However, in certain local cases, faculty management prefers to believe the student rather than the professor. Looking at the timeline, these acts of harassment and insubordination in academia come with the changing periods (Henning et al., 2017). Insubordination and incivility from a student to a professor or juniors towards seniors are no longer isolated cases, as stated by Holm, Torkelson, and Bäckström (2019).

If these cases have occurred at universities in developed nations, there is a certainty that such incivility is another silent enemy in workplace happiness for developing countries, such as Malaysia.

\subsection{Extant of Workplace Incivility}

The extent of workplace incivility is troubling, particularly in a university setting. Bullying and mobbing are two examples of workplace incivility. As noted by Hollis (2015), workplace incivility has a detrimental effect on employees. In cases where faculty members alert university management on bullying incidence, the economic and organizational costs are significant (ibid). The most significant factor would be backlash through employee disengagement and other associated costs that would be detrimental to university collegiality and workplace happiness. According to Hollis (2015), the victims who resigned because of mobbing were often high performing ones. The replacement cost for the departed, skilled human resource was significant.

Concerning incivility by gender, Namie and Namie (2009) reported that women colleagues bullied $71 \%$ of women. Relating this to insider feedbacks in a university environment, the bullies are junior staff holding positions of power, such as being a member of the faculty management; this is termed as vicarious bullying (Hollis, 2015). The acts of intimidation and mobbing were usually condoned by a superior, such as the dean of the faculty. Else, the seed of workplace incivility would not have been planted. As opined by Hollis (2015), a leader will use this tactic to continue intimidation in his or her absence. This is in an attempt to preserve a façade of kindness while using subversive tactics to control the staff. The power imbalance between the victim and the perpetrator often left the former defenseless (Hollis, 2015). Once the culture of incivility has been set, eradicating the unethical acts would be difficult.

Nonetheless, the extent of workplace incivility has resulted in $40 \%$ resignations, and only $24 \%$ were fired. The most troubling result was that $44 \%$ of the time, the organization did nothing to provide relief to the targets or victims, and, in $18 \%$ of the cases, the situation became more intensified for the victim once the bullying was reported (Namie \& Namie, 2009). Table 1 lists the occurrences of bullying and mobbing in academia from 1994 to 2019. These are just some of the sources indicating the prevalence of the silent enemy of mobbing.

\subsection{Why do perpetrators bully or mob?}

On the flip side of being the victim of bullies, there must be reasons why the perpetrators mob. According to Nyborg (2012), the oftcited motivation for relational aggression was jealousy. From the insider researcher's standpoint, the bullying or mobbing by individuals of the same work and environment was because of envy, covetousness, and greed. They may be intellectuals with doctorate degrees, but jealousy can lead to irrational behavior (Keashly \& Neuman, 2010; Keashly \& Wajngurt, 2016). The application of Bandura's eight moral disengagement strategies can be used to understand the reasons for academic violence through bullying or mobbing (Miller et al., 2019). Bandura (2016) stated that there are psychosocial mechanisms by which people selectively disengage their moral selfsanctions from their harmful conduct or bullying. They do this by:

- sanctifying their harmful behavior as serving worthy causes

- absolving themselves of the blame for the harm they cause by displace and diffusion of responsibility

- minimizing or denying the detrimental effects of their actions

- dehumanizing those they maltreat and blame them for bringing the suffering on themselves

In other words, the perpetrator thinks that they are doing justice by bullying or mobbing the faculty member. If this aggressive behavior is allowed to prevail, there are possibilities of other mental health issues plaguing the academia. In agreement with McKay, Arnold, Fratzl, and Thomas (2008), workplace bullying and mobbing in academia are of particular concern for new or junior faculty members. The spillover effect indicates costs for the university, such as employee turnover, changed the perception of the university, reduced employee engagement (ibid), and, most importantly, reduction in happiness and job satisfaction at work. Culture change is required for this matter (Barratt-Pugh \& Krestelica, 2019), including profiling mobber behavior (Minibas-Poussard, Seckin-Celik, \& Bingol, 2018). 
Table 1. Summary of University-Workplace Mobbing

\begin{tabular}{|c|c|c|}
\hline Article Title & Year & Comments \\
\hline $\begin{array}{l}\text { Mobbing at Workplace-Psychological trauma and } \\
\text { documentation of psychiatric symptoms }\end{array}$ & 2019 & $\begin{array}{l}\text { Mobbing was identified in } 43.3 \% \text { and } \\
\text { has been subjected to trauma at the } \\
\text { workplace. }\end{array}$ \\
\hline Bullying and Mobbing Academe: A literature review & 2018 & $\begin{array}{l}25 \%-91 \% \text { of academics are mobbed in } \\
\text { the workplace. The most common } \\
\text { types of bullying are undermining of } \\
\text { professional competence }\end{array}$ \\
\hline $\begin{array}{l}\text { My campus administration, faculty association and me: } \\
\text { Academic mobbing and sweetheart unionism }\end{array}$ & 2018 & $\begin{array}{l}\text { Reported incidences of academic } \\
\text { mobbing }\end{array}$ \\
\hline $\begin{array}{l}\text { Mobbing and bullying among physicians-when } \\
\text { colleagues become enemies }\end{array}$ & 2018 & $\begin{array}{l}\text { The prevalence of mobbing is } \\
\text { exceptionally high in health care in } \\
\text { universities }\end{array}$ \\
\hline $\begin{array}{l}\text { Bullying in higher education: Culture change requires } \\
\text { more than policy }\end{array}$ & 2018 & $\begin{array}{l}\text { The pervasive and corrosive impact of } \\
\text { workplace bullying appears culturally } \\
\text { resilient despite policy regimes }\end{array}$ \\
\hline $\begin{array}{l}\text { Toxic workplace environment and its impact on women } \\
\text { professors in the United States: The imperative need for } \\
\text { therapeutic jurisprudence practices in higher education }\end{array}$ & 2017 & $\begin{array}{l}\text { There is a prevalence of academic } \\
\text { mobbing and the effects of toxicity on } \\
\text { women professors in the academy. }\end{array}$ \\
\hline $\begin{array}{l}\text { Workplace harassment among staff in higher education: } \\
\text { A systematic review }\end{array}$ & 2017 & $\begin{array}{l}\text { Workplace harassment in higher } \\
\text { education adversely impacts workforce } \\
\text { productivity and victims' health }\end{array}$ \\
\hline $\begin{array}{l}\text { The mediator role of social safeness and pleasure in the } \\
\text { relation between mobbing and meaning of work in } \\
\text { academicians }\end{array}$ & 2016 & $\begin{array}{l}\text { Mobbing is a widespread problem in } \\
\text { higher education }\end{array}$ \\
\hline $\begin{array}{l}\text { Academicians' perceptions of mobbing at universities: } \\
\text { Dokus EEylul University case }\end{array}$ & 2015 & $\begin{array}{l}\text { Schools/faculties with the fewest } \\
\text { academicians experience more } \\
\text { mobbing incidences }\end{array}$ \\
\hline $\begin{array}{l}\text { Organizational sequestering of workplace bullying: } \\
\text { Adding insult to injury }\end{array}$ & 2015 & $\begin{array}{l}\text { Despite recommendations that } \\
\text { organizations take workplace bullying } \\
\text { seriously and increasing research on } \\
\text { the issue, little evidence exists of } \\
\text { improvements by the management }\end{array}$ \\
\hline $\begin{array}{l}\text { Assessment of mobbing behaviors exposed by the } \\
\text { academic personnel working in a University in Turkey }\end{array}$ & 2015 & $\begin{array}{l}\text { Workplace mobbing is a critical } \\
\text { problem for academicians. The most } \\
\text { common threatening behavior was an } \\
\text { assault on professional status. The } \\
\text { primary mobbers were the superiors. }\end{array}$ \\
\hline $\begin{array}{l}\text { The exposure of psychological violence (mobbing( in } \\
\text { universities and an application to the academicians }\end{array}$ & 2013 & $\begin{array}{l}\text { Single, young and small-staff Faculty } \\
\text { of Education, Turkey is more exposed } \\
\text { to mobbing behaviors }\end{array}$ \\
\hline An economic model of workplace mobbing in academe & 2012 & $\begin{array}{l}\text { Workplace mobbing remains a } \\
\text { prevalent issue in academe }\end{array}$ \\
\hline $\begin{array}{l}\text { Perception of faculty members exposed to mobbing } \\
\text { about the organizational culture and climate }\end{array}$ & 2010 & $\begin{array}{l}\text { Weak and unfavorable organizational } \\
\text { culture triggers psycho-violence }\end{array}$ \\
\hline Mobbing: Workplace violence in the academy & 2010 & $\begin{array}{l}\text { Mobbing and bullying of faculty by } \\
\text { other faculty are types of workplace } \\
\text { violence that are becoming common. }\end{array}$ \\
\hline Workplace bullying in academia: A Canadian study & 2008 & $\begin{array}{l}\text { The findings indicate costs for the } \\
\text { university because of workplace } \\
\text { bullying }\end{array}$ \\
\hline Aggression among university employees & 1994 & $\begin{array}{l}\text { Female university employees } \\
\text { experience more harassment. } \\
\text { Individuals in superior positions harass } \\
\text { their subordinates more than the other } \\
\text { way around }\end{array}$ \\
\hline
\end{tabular}

\subsection{Methodology}

For most review articles, the method works along the lines of systematic analyses of relevant publications and grey literature using keywords on the topic researched. The specificity of the keywords was through synonyms so as not to stray from the focus of the investigation. Also, the narrative lens analysis is used as the investigative focus for this article, as stated by Feldman, Skoldberg, Brown, and Horner (2004). As noted, narratives are useful data as respondents give feedback in the form of stories (Cohen \& Crabtree, 2006 July). Therefore the descriptions for this paper were summaries and systematic interpretation by the authors from the compilation of relevant literature. 


\subsection{Findings and Discussion}

Articles that met the inclusion criteria for the paper's aims are shown from the summary in Table 1. Some relevant sources were not included in Table 1 but were dissected in the literature review section. From various readings, the published issue on bullying and mobbing between faculty members in higher education began in the 1980s. The item has sparked other spectra of research on this phenomenon from various perspectives; the perpetrator, the victim, and the university in managing faculty mobbing and bullying.

From the literature surveyed, colleagues were identified as bullies from their faculty members, regardless of junior or senior status. Typically, it is stereotyped that bullying and mobbing would be from someone older, holds a higher position, or more prominent is physical size. Times have changed, and the bullying incidences have shown this. However, the reason for bullying remains the same because of jealousy and envy. On another note, the average time that bullying or mobbing has occurred is found to be more than five years; this is too long a time for the faculty or university management to ignore. For some universities, there is an integrity division formed to investigate any misconduct by the university staff. It is advised that the integrity division maintains sound integrity values when investigating cases, regardless of the individuals involved.

For public universities in Malaysia, it should not be a surprise that bullying and mobbing do occur. Although most academic staff hold to religious and cultural values, these misconducts and aggression towards a fellow faculty member do happen in the new era of bullying. The extent of the bullying or mobbing may differ, but once reported to the Integrity Division, proper and fair investigations must be practiced. Another facet on faculty bullying or mobbing is the blame game. The victim is usually blamed for allowing these acts of aggression, especially if they are junior faculty members. On the opposite side, when the senior is being victimized, the blame is still on the senior, not the aggressors. To reiterate, the school or faculty management and the university administrators must be fair and just in handling these cases. Do not take too long to conclude the investigation and penalize the perpetrator.

Finally, the findings from the review paper indicated that mobbing is endemic at universities. Faculty mobbing is a threat to the university's image and reputation and should be treated as a significant element in workplace unhappiness. For universities in Malaysia, academic management should heed whistleblowers' reports. In a place where intellectuals congregate, mobbing can become an infectious disease among the junior academicians in their haste for promotion and accolades. The severity of faculty mobbing should be contained at an early stage by ethical mentoring.

\subsection{Conclusion and Recommendation}

Without a doubt, university workplace and faculty mobbing are silent enemies that have become endemic and damaging if allowed to manifest. The university management must contain bullying and mobbing activities at the start. Whistleblowing reports on faculty mobbing should not be taken lightly and should be treated with utmost urgency. Public universities, especially, should uphold the integrity of the organization. For academicians to be happy at the university, there is a need to improve the situation to preserve the auspices of academia.

\section{Acknowledgments}

We would like to acknowledge the Ministry of Education, Malaysia, for awarding the Fundamental Research Grant Scheme (FRGS 053/2017). We would also like to acknowledge Universiti Teknologi MARA, Cawangan Selangor, for the research management support.

\section{References}

Bandura, A. (2016). Moral disengagement: How people do harm and live with themselves. New York, NY, US: Worth Publishers.

Barratt-Pugh, L. G. B., \& Krestelica, D. (2019). Bullying in higher education: culture change requires more than policy. Perspectives: Policy and Practice in Higher Education, 23(2-3), 109-114 doi:10.1080/13603108.2018.1502211

Cohen, D., \& Crabtree, B. (2006 July). Qualitative Research Guidelines Project: Narrative Analysis. Retrieved from http://www.qualres.org/HomeNarr-3823.html

Duffy, M., \& Sperry, L. (2012). Mobbing: Causes, Consequences, and Solutions.

Feldman, M. S., Skoldberg, K., Brown, R. N., \& Horner, D. (2004). Making sense of stories: A rhetorical approach to narrative analysis. Journal of Public Administration Research and Theory, 14(2), 147-170. doi:10.1093/jopart/muh010

Henning, M. A., Zhou, C., Adams, P., Moir, F., Hobson, J., Hallett, C., \& Webster, C. S. (2017). Workplace harassment among staff in higher education: a systematic review. Asia Pacific Education Review, 18(4), 521-539. doi:10.1007/s12564-017-9499-0

Hollis, L. P. (2015). Bully university? The cost of workplace bullying and employee disengagement in American higher education. Sage Open, 5(2), 2158244015589997.

Holm, K., Torkelson, E., \& Bäckström, M. (2019). Exploring links between witnessed and instigated workplace incivility. International Journal of Workplace Health Management, 12(3), 160-175. doi:10.1108/IJWHM-04-2018-0044

Keashly, L., \& Neuman, J. H. (2010). Faculty experiences with Bullying in Higher Education: Causes, consequences, and management. Administrative Theory \& Praxis, $32(1), 48-70$

Keashly, L., \& Wajngurt, C. (2016). Faculty bullying in higher education. Psychology and Education, 53(1-2), 79-90. 
Keim, J., \& McDermott, J. C. (2010). Mobbing: Workplace violence in the academy. Educational Forum, 74(2), 167-173. doi:10.1080/00131721003608505

Lampman, C., Phelps, A., Bancroft, S., \& Beneke, M. (2009). Contrapower Harassment in Academia: A Survey of Faculty Experience with Student Incivility, Bullying, and Sexual Attention. Sex Roles, 60(5-6), 331-346. doi:10.1007/s11199-008-9560-x

Lester, J. (2013). Bullying in higher education: What current research, theorizing, and practice tell us Workplace bullying in higher education (pp. 15-36): Routledge. Lester, J. E. (2013). Workplace bullying in higher education: Routledge.

May, A., \& Tenzek, K. E. (2018). Bullying in the academy: understanding the student bully and the targeted "stupid, fat, mother fucker' professor. Teaching in Higher Education, 23(3), 275-290. doi:10.1080/13562517.2017.1379482

McKay, R., Arnold, D. H., Fratzl, J., \& Thomas, R. (2008). Workplace Bullying In Academia: A Canadian Study. Employee Responsibilities and Rights Journal, 20(2), 77-100. doi:10.1007/s10672-008-9073-3

Miller, G., Miller, V., Marchel, C., Moro, R., Kaplan, B., Clark, C., \& Musilli, S. (2019). Academic Violence/Bullying: Application of Bandura's Eight Moral Disengagement Strategies to Higher Education. Employee Responsibilities and Rights Journal, 31(1), 47-59. doi:10.1007/s10672-018-9327-7

Minibas-Poussard, J., Seckin-Celik, T., \& Bingol, H. B. (2018). Mobbing in higher education: Descriptive and inductive case narrative analyses of mobber behavior, mobbee responses, and witness support. Kuram ve Uygulamada Egitim Bilimleri, 18(2), 471-494. doi:10.12738/estp.2018.2.0018

Namie, G., \& Namie, R. (2009). The bully at work: What you can do to stop the hurt and reclaim your dignity on the job. Naperville, IL: Sourcebooks.

Nyborg, D. G. (2012). Sabotaging our sisters: Perceptions of female relational aggression in higher education among female faculty and administrators at three western U.S. universities. (3536199 Ed.D.), Idaho State University, Ann Arbor. Retrieved from

http://search.proquest.com.ezaccess.library.uitm.edu.my/docview/1292616220?accountid=42518 ProQuest Dissertations \& Theses Global database.

Prevost, C., \& Hunt, E. (2018). Bullying and Mobbing in Academe: A literature. European Scientific Journal, 14(8), 15. doi:10.19044/esj.2018.v14n8p1

Thirlwall, A. (2015). Organisational sequestering of workplace bullying: Adding insult to injury. Journal of Management and Organization, 21(2), 145-158. doi:10.1017/jmo.2014.72 